\title{
Cognitive behavioural therapy in virtual reality treatments across mental health conditions: a systematic review
}

\author{
Применение когнитивно-поведенческой терапии в формате виртуальной \\ реальности при различных психических состояниях: систематический обзор \\ DOI: 10.17650/2712-7672-2020-1-1-30-46
}

\author{
Merve Dilgul ${ }^{1,2}$, Jasmine Martinez, ${ }^{1,2}$, Neelam \\ Laxhman $^{1,2}$, Stefan Priebe ${ }^{1,2}$ and Victoria Bird ${ }^{1,2}$ \\ ${ }^{1}$ Unit for Social and Community Psychiatry, Queen Mary \\ University of London, UK; ${ }^{2}$ East London NHS Foundation \\ Trust, UK.
}

\author{
Мёрв Дилгул ${ }^{1,2}$, Жасмин Мартинес ${ }^{1,2}$, Нилэм \\ Лаксман ${ }^{1,2}$, Стефан Прибэ ${ }^{1,2}$, Виктория Бёрд ${ }^{1,2}$ \\ 'Отделение социальной и общественной психиатрии, \\ Лондонский университет королевы Марии, Лондон, \\ Великобритания; ${ }^{2}$ Фонд Начиональной службы \\ здравоохранения, Восточный Лондон, Великобритания.
}

\begin{abstract}
Background. Virtual reality (VR) has been effectively used in the treatment of many mental health disorders. However, significant gaps exist in the literature. There is no treatment framework for researchers to use when developing new VR treatments. One recommended treatment across a range of diagnoses, which may be suitable for use in VR treatments, is Cognitive Behavioural Therapy (CBT). The aim of this systematic review is to investigate CBT treatment methods that utilize VR to treat mental health disorders.
\end{abstract}

Objectives. To investigate how CBT has been used in VR to treat mental health disorders and to report on the treatment characteristics (number of sessions, duration, and frequency) that are linked to effective and ineffective trials.

Methods. Studies were included if patients had a mental health diagnosis and their treatment included immersive VR technology and CBT principles. Data were extracted in relation to treatment characteristics and outcomes, and analysed using narrative synthesis.

Results. Ninety-three studies were analysed. Exposure-based VR treatments were mainly used to treat anxietyrelated disorders. Treatments generally consisted of eight sessions, once a week for approximately one hour. VR treatments were commonly equal to or more effective than 'traditional' face-to-face methods. No specific treatment characteristics were linked to this effectiveness.

Conclusion. The number, frequency and duration of the VR treatment sessions identified in this review, could be used as a treatment framework by researchers and clinicians. This could potentially save researchers time and money when developing new interventions.

\section{АННОТАЦИЯ}

Введение. Виртуальная реальность (ВР) эффективно применяется при лечении многих психических расстройств. Тем не менее информации в литературе об использовании этого подхода недостаточно. В частности, отсутствуют данные по формату лечения, который могли бы использовать исследователи 
при разработке новых методов ВР-терапии. Одним из рекомендованных методов терапии при широком спектре диагнозов, который может применяться в формате ВР, является когнитивно-поведенческая терапия.

Цели. Изучить использование методов когнитивно-поведенческой терапии с применением технологии ВР для лечения психических расстройств и определить характеристики лечебного процесса (количество сессий, продолжительность и частота), которые оказались эффективны и неэффективны.

Материал и методы. В обзор включали исследования, проводившиеся с участием пациентов сустановленным диагнозом психического расстройства, в лечении которых использовались технологии ВР с эффектом присутствия и принципы когнитивно-поведенческой терапии. Извлекали данные, связанные схарактеристиками и исходами лечения, и анализировали их с использованием описательного синтеза.

Результаты. Было проанализировано 93 исследования. Экспозиционная ВР-терапия преимущественно применялась для лечения тревожных расстройств. Терапия обычно включала 8 сеансов 1 раз в неделю длительностью около 1 часа. ВР-терапия обычно была так же эффективна, как традиционные методы работы «лицом к лицу», либо эффективней их. Эффективность не была связана с какими-либо специфическими характеристиками терапии.

Выводы. Количество, частота и длительность сеансов ВР-терапии, выявленные в данном обзоре, могут использоваться для определения формата лечения исследователями и клиницистами. Это потенциально способно сократить время и средства, затрачиваемые исследователями при разработке новых вмешательств.

Keywords: Virtual Reality, Digital Interventions, Narrative Analysis, Mental Health Treatment, Cognitive Behavioural Therapy

Ключевые слова: виртуальная реальность, чифровые вмешательства, описательный анализ, терапия психических расстройств, когнитивно-поведенческая терапия

\section{INTRODUCTION}

Virtual reality (VR) is a technological interface that allows users to experience computer-generated environments within a controlled setting [1]. Recent meta-analyses and systematic reviews have found this technology to be an effective tool in the treatment of a range of mental health conditions [2], with most evidence derived from anxiety-related disorders [3], eating disorders [4] and psychosis [5].

In addition to its treatment effectiveness, VR exposure therapy has been found to be more cost-effective than face-to-face treatment for posttraumatic stress disorder [6]. Furthermore, VR treatments are well accepted by patients, who have expressed high levels of support and interest in its use for their mental health treatment [7]. There is also evidence that drop-out rates may be lower with VR treatments than with traditional face-to-face treatments [8]. This technology may, therefore, potentially improve access and adherence to psychological treatments $[7,8]$.

Despite the potential of VR in mental health treatment, significant gaps exist in the literature relating to VR treatment. Studies in the literature have mainly focused on treating anxiety disorders with exposure-based therapies and have overlooked other diagnoses (e.g., depression, bipolar and personality disorder) and other treatment possibilities (e.g., guided self-help) [8].

A framework is a basic structure that underlies a system or concept, and may be built on or used as a point of reference to decide upon a particular course of action [9]. To our knowledge, there are no shared VR treatment frameworks currently available for researchers to follow. Without a treatment framework on which to build, researchers who want to explore new VR treatment methods for overlooked diagnoses, are forced to spend a great deal of time and money to develop their own treatments, which may or may not 
be successful [10]. The potential risks associated with not having a treatment framework, may constitute a barrier to new VR treatment methods.

One recommended treatment across a range of diagnoses [11], which may be suitable for use in VR treatments, is cognitive behavioural therapy (CBT). CBT is based on the cognitive model of mental illness and this model hypothesizes that the way in which patients feel and behave, is determined by their perception of situations, rather than the actual situations [12]. CBT aims to relieve distress by helping patients develop more adaptive cognitions and behaviours [13]. Developing a treatment framework that summarizes effective VR CBT treatment characteristics (e.g., the number of sessions, duration and frequency) could provide a possible foundation upon which researchers can build. This could potentially reduce the time and money spent on the development of interventions.

At present, no research has synthesized VR treatment characteristics across diagnoses. The aim of this systematic review is to explore CBT treatment methods that utilize VR to treat mental health disorders. A treatment framework will be developed from the identified shared treatment characteristics (e.g., the number of sessions, duration and frequency).

\section{Objectives}

The objectives of this systematic review are to:

1 investigate how CBT has been used in VR to treat mental health disorders.

2 report on the treatment characteristics (number of sessions, duration, and frequency) that are linked to effective and ineffective trials.

\section{METHODS}

The study protocol for this systematic review and narrative synthesis was registered on PROSPERO [CRD42018106757].

\section{Identification of studies}

The eligibility criteria were developed using the PICO framework [14]. Papers were eligible if they were written in English, the study participants had to be over the age of 18 with any mental health diagnosis, using recognized diagnostic criteria (ICD-10 or DSM-V) or a validated scale with a pre-defined cut off point. To be included in the review, the interventions in the studies had to use principles of CBT, as defined by the NHS [15]. Furthermore, the VR technology used, had to be immersive. Immersive VR is defined as a computersynthesized virtual environment surrounding the user. This can include (but is not restricted to) a headmounted display (HMD) and a Cave automatic virtual environment (CAVE). An HMD consists of a computergenerated video display attached to the user's head, with retina or head trackers that measure the changing position, which is fed back to the rendering computer [16]. A CAVE is essentially a room in which computergenerated visual imagery is projected onto the walls, floor and ceiling, and the user is free to move around [17]. Papers were excluded if they did not have an experimental design (e.g., case series and reviews) and if the treatment procedures were not reported. All comparators and mental health-related outcomes were taken into consideration, including treatment effectiveness, feasibility, adherence and attrition.

A literature search of PubMed, CINAHL, EMBASE, PsycINFO, the Cochrane Library and NICE Healthcare Databases Advanced Search was conducted in August 2018. Grey literature was also searched using OpenGrey and Google Scholar. The search strategy was developed by identifying relevant key terms, used in a previous VR review [8] and was further developed in conjunction with an information scientist. The general search terms were: 'virtual reality' AND 'cognitive behavioural therapy' AND disorder-specific terms (see Appendix A for full search terms). Databases were searched from inception for titles, abstracts and keywords. Four key papers were identified and used to assess the reliability of the search results $[1,8,18,19]$. The authors also conducted hand searches of the Annual Review of CyberTherapy and Telemedicine and the reference list of relevant papers. Study authors were contacted when access issues occurred.

\section{Study selection}

Identified references were transferred into Endnote and duplicates removed. The references were then transferred into an Excel spreadsheet. The first reviewer (MD) screened all the titles and abstracts, whereas the second reviewer (NL) independently screened $25 \%$. Subsequently, the full text of the potentially relevant papers was retrieved and was once again independently assessed for eligibility by 
both reviewers. Hereafter, the reasons for exclusion were noted in the database. The inter-rater reliability for screening between the authors (MD and $\mathrm{NL}$ ) using Cohen's Kappa was moderate $(60 \%$ agreement, $\mathrm{p}<.0001)$. Any disagreements throughout the screening process were resolved through discussion and, if necessary, by involving a third reviewer (VB).

A data extraction framework was created using Excel and piloted with five studies. The data extracted included general information relating to the study eligibility, methods, VR treatment descriptions and a summary of the results, outcomes and conclusions.

Data were analysed using narrative synthesis [20]. Some treatment characteristics such as number and duration of sessions, were reported numerically, other treatment characteristics such as type of VR technology used and treatment location, were simplified into categorical variables for quantitative synthesis. This was to allow synthesis and integration of a large amount of data across the dataset. The quantitative data were imported into SPSS to allow for vote counting and for the statistical testing of differences. Vote counting and quantitative synthesis (e.g., t-tests and Chi-squared) were used to develop a preliminary synthesis, as they allowed the researchers to identify patterns across the included studies [20].

The first objective of this review was to investigate how CBT has been used in VR to treat mental health disorders. Once the treatment characteristics of all of the 93 studies were synthesized, the first objective of this review had been achieved.

The second objective was to report on the treatment characteristics that are linked to effective and ineffective trials. Studies which aimed to explore VR treatment effectiveness (62 out of the 93 studies) were selected for the second analysis. These studies were categorized according to their aims and were analysed separately.

Finally, treatment characteristics of studies which found VR to be more effective by comparison with 'traditional' treatment methods (e.g., in-vivo exposure) were compared with studies which found VR to be ineffective when compared with 'traditional' treatment methods. To allow for a clear comparison, studies which were equally effective using 'traditional' methods were excluded from this analysis.

\section{Risk of bias}

The two reviewers (MD and NL) independently assessed the risk of bias using the Quality Assessment Tool for Quantitative Studies [21]. This tool has been specially developed for public health research and assesses six components of bias and quality; these include selection bias, study design, confounders, blinding, data collection methods, withdrawals and dropouts. The inter-rater reliability between the authors, using Cohen's Kappa was high $(80 \%$ agreement, $\mathrm{p}<.001)$. Any disagreements between the two reviewers were resolved through discussion or by consulting a third reviewer (JM). The results of the quality analysis were further tabulated to identify any types of bias common to the included studies.

\section{RESULTS}

The study selection process and a summary of the included studies will be presented first, followed by a general overview of the quality of the included studies. Next the main results will be presented, according to the two review objectives; 1 ) how CBT has been used in VR to treat mental health disorders and 2) which are the treatment characteristics that are linked to effective and ineffective trials.

\section{Selection and inclusion of studies}

Once duplicates were removed, the search generated 2273 references, of which 129 papers met the review inclusion criteria. The 129 papers reported on 93 separate studies; 36 papers reported follow-up data or secondary data analysis of the original 93 included studies. The 36 papers were combined with their original studies and analysed together. The most common reason for exclusion was the use of non-immersive technology (e.g., studies using computer screens). See Figure 1 for the PRISMA flow diagram.

\section{Characteristics of included studies}

Anxiety-related disorders were the most frequently studied group $(n=80)$, followed by eating disorders $(n=6)$, psychosis $(n=3)$, substance disorder $(n=3)$ and finally, one study relating to depression. The majority of the studies were randomized control trials $(n=48)$, followed by cohort studies ( $n=27)$, non-randomized clinical trials $(n=8)$ and other designs $(n=9)$. The average sample size across the studies was 41 (range 4 -162), ( $M=40.7, S D=35.9, n=93)$. 


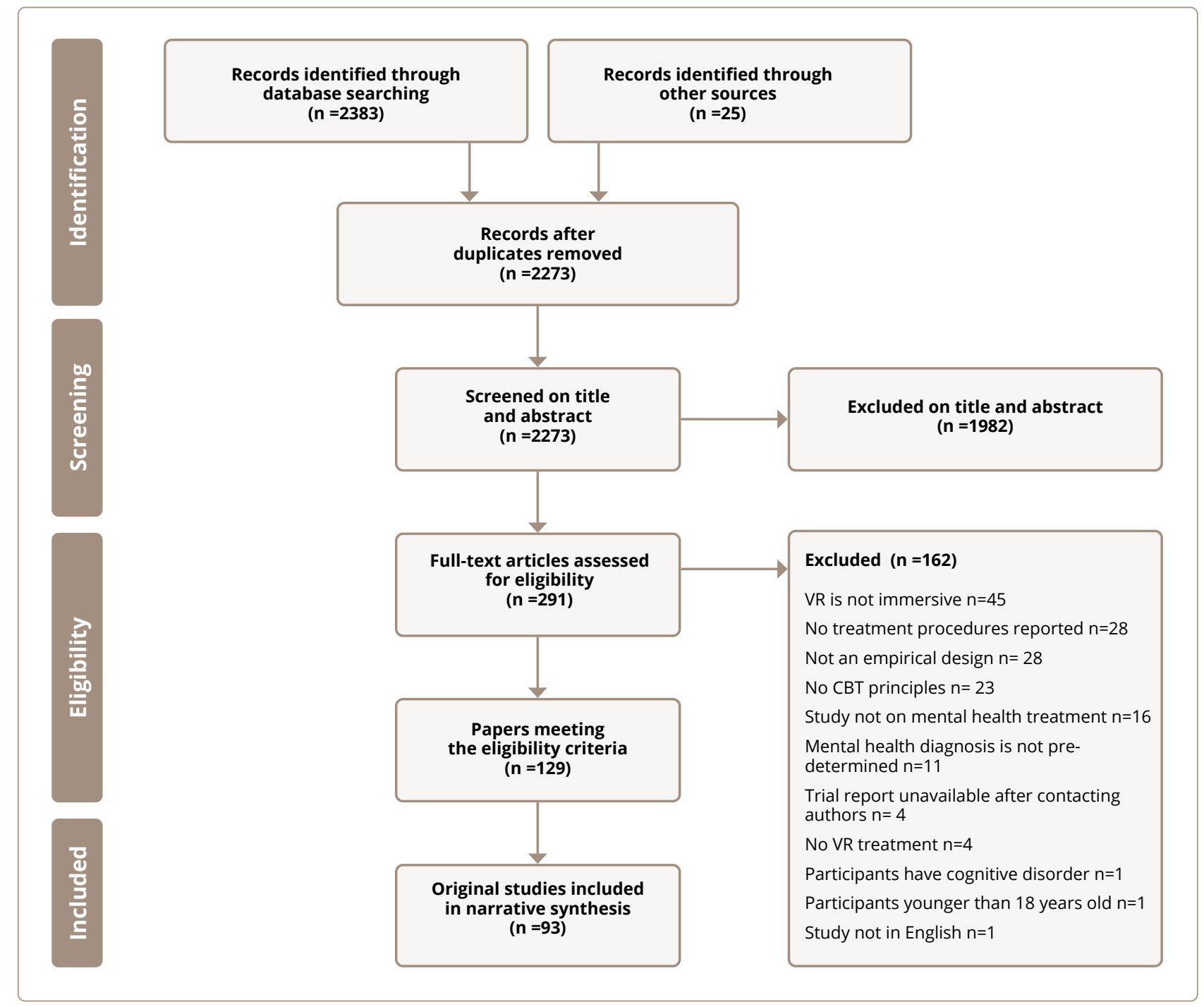

Figure 1. PRISMA flow diagram of the study selection process

Table 1. Breakdown of the quality assessment

\begin{tabular}{|l|l|l|l|l|l|l|}
\hline $\begin{array}{l}\text { Quality } \\
\text { assessment }\end{array}$ & $\begin{array}{l}\text { Selection } \\
\text { bias rating }\end{array}$ & $\begin{array}{l}\text { Study design } \\
\text { rating }\end{array}$ & $\begin{array}{l}\text { Confounding } \\
\text { variable rating }\end{array}$ & $\begin{array}{l}\text { Blinding } \\
\text { rating }\end{array}$ & $\begin{array}{l}\text { Data } \\
\text { collection } \\
\text { rating }\end{array}$ & $\begin{array}{l}\text { Withdrawal } \\
\text { rating }\end{array}$ \\
\hline Strong & 16 & 55 & 75 & 8 & 48 & 47 \\
\hline Moderate & 36 & 37 & 5 & 18 & 20 & 20 \\
\hline Weak & 41 & 1 & 13 & 67 & 25 & 26 \\
\hline Mode & Weak & Strong & Strong & Weak & Strong & Strong \\
\hline
\end{tabular}


Quality assessment and risk

\section{of bias in included studies}

The quality of the studies in this review was found to be predominately weak (see Appendix B for individual study quality assessment). A table was formulated to explore why studies were often of poor quality (Table 1 ).

The poor quality of the studies can be attributed to selection bias. Most studies either did not report where they recruited their patients from, or they recruited volunteers through advertising. This may have resulted in lower than anticipated drop-out rates, as volunteers might have been more willing to participate. Furthermore, although logistically difficult, most studies did not blind the patients or the assessors to the treatment intervention. This may have resulted in assessment bias.

A cross-tabulation between the quality of studies and the year of publication showed that the quality of studies has not improved over time.

\section{How has CBT been used in VR to treat}

\section{mental health disorders?}

To address the primary aim of the review, the common characteristics of treatments will be described. For a summary of the treatment characteristics, please view the second column of Table 2 .

VR has generally been used as a component in a more extensive treatment protocol $(n=58)$. On average, patients were offered eight treatment sessions, and six of these sessions involved VR technology. The first and the last sessions were psychoeducational, e.g., identifying symptoms and discussing relapse prevention [22]. Treatment was usually delivered once a week for an average of 78 minutes. The average duration of the VR component in these sessions was 53 minutes.

VR treatment was primarily delivered using an HMD device. In all the studies, patients were treated individually in the virtual environment. The VR treatment was generally delivered by therapists $(n=38)$, although only nine studies provided details on the clinical training of the therapist, which included graduate and postgraduate therapists.

The majority of the studies did not report the location of the therapy, however, where the location was explicitly stated, treatments were generally administered in a therapist's office / clinic. A typical VR treatment session would involve the patient wearing an HMD, connected to a computer, which is controlled by the therapist.
Virtual reality exposure therapy (VRET) was the most frequently delivered CBT treatment (84 of the 93 studies). During VRET, patients are gradually exposed to a virtual environment that provokes anxiety, e.g., a battlefield in the case of patients with post-traumatic stress disorder [23], or exposure to a spider for patients with arachnophobia [22]. The aim is that patients become desensitized to the fear-provoking stimuli with gradual exposure.

VRET was the most commonly used treatment in this review. Across the nine remaining studies, there was some variation in the definitions used to describe the CBT treatments, e.g., VR enhanced CBT, VR cognitive therapy and repeated behavioural experiment tests. These treatments will be discussed together. Similar to VRET, these treatments all used VR to expose patients to specific, anxiety-provoking virtual environments. However, unlike VRET, the aim of exposure was not just to desensitize the patient to a situation, but to trigger certain emotions or behaviours that therapists can subsequently work on with the patient. For instance, in an eating disorder study, patients were exposed to virtual environments that were thought to trigger emotions related to weight, e.g., restaurants, clothes shopping and a swimming pool. In these environments, patients performed virtual tasks such as weighing themselves and trying on clothes, whilst the therapist discussed feelings and beliefs [24]. Similarly, Pot-Kolder et al. (2018) [26] used VR to expose patients with persecutory delusions and paranoid ideation to stressful social environments, that could trigger fear and paranoid thoughts, e.g., being on the underground or in a café. In these virtual environments, they explored and challenged the patient's suspicious thoughts and safety behaviours, and tested harm expectancies.

One study [27] used automated, repeated behavioural experiments for the treatment of a fear of heights. In the virtual environment, patients were guided by a virtual coach to explore and perform height-related tasks (e.g., saving a cat from a high level). In doing this, patients explored how safe they felt at certain virtual heights and often found that they felt safer than they expected.

What are the treatment characteristics that are linked to effective and ineffective trials?

Studies included in this review varied as to their primary aim; not all the studies investigated or reported treatment effectiveness. Therefore, this section will first 


\begin{tabular}{|c|c|c|c|c|c|c|c|c|c|c|}
\hline 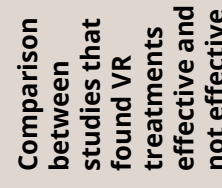 & 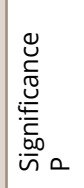 & g. & $\begin{array}{l}\infty \\
0 \\
0\end{array}$ & $\hat{o}$ & $\stackrel{\circ}{\circ}$ & 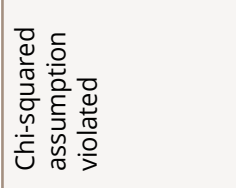 & 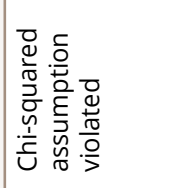 & 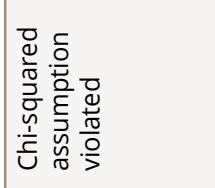 & 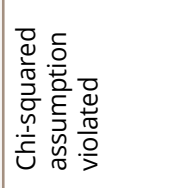 & 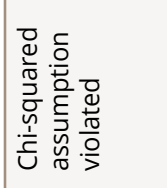 \\
\hline \multirow{2}{*}{ 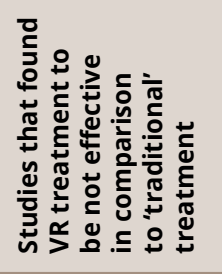 } & 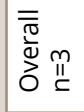 & $m$ & $m$ & $m$ & $m$ & $\sim$ & $m$ & $m$ & $\sim$ & $m$ \\
\hline & 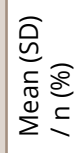 & $\begin{array}{l}0 \\
0 \\
0 \\
0 \\
\dot{0} \\
-\end{array}$ & 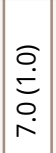 & 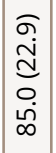 & 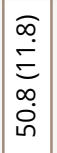 & 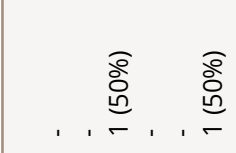 & 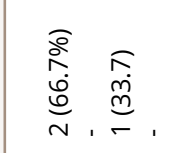 & 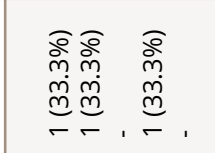 & , & $\begin{array}{l}\text { òे } \\
\text { ò } \\
\text { c }\end{array}$ \\
\hline \multirow{2}{*}{ 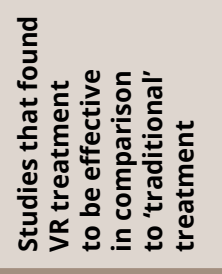 } & 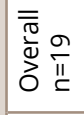 & $\stackrel{\infty}{\leftarrow}$ & $\stackrel{\infty}{\sim}$ & 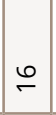 & 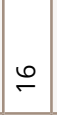 & 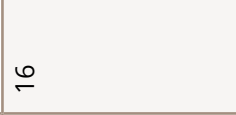 & $\stackrel{\mathscr{\Omega}}{?}$ & 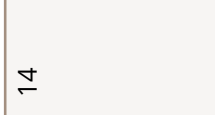 & $\stackrel{\circ}{\circ}$ & $\stackrel{9}{?}$ \\
\hline & 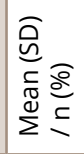 & $\begin{array}{l}\frac{\pi}{n} \\
\stackrel{n}{n} \\
\sigma\end{array}$ & 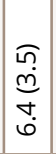 & $\begin{array}{l}\tilde{m} \\
\tilde{\rho} \\
\tilde{m} \\
\hat{\sim} \\
\dot{N}\end{array}$ & 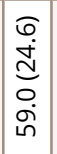 & 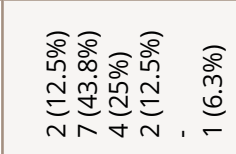 & 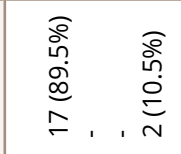 & 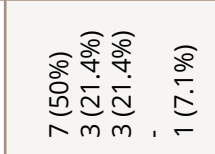 & 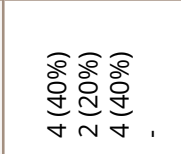 & 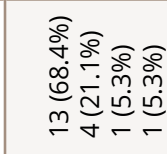 \\
\hline \multirow{2}{*}{ 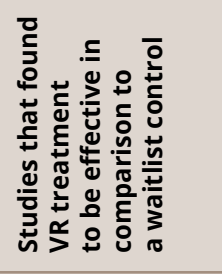 } & 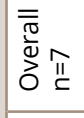 & in & in & 0 & in & 0 & $\wedge$ & $\wedge$ & 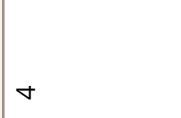 & $\wedge$ \\
\hline & 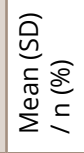 & 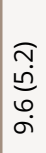 & 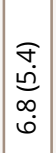 & 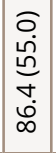 & 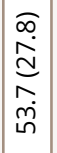 & , & 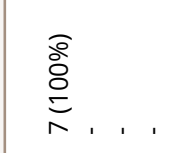 & 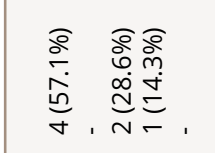 & 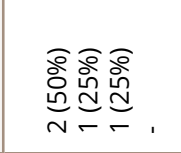 & 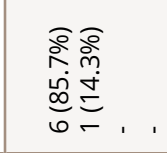 \\
\hline \multirow{2}{*}{ 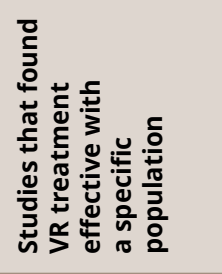 } & 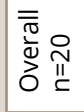 & $\stackrel{\infty}{\leftarrow}$ & $\stackrel{\sim}{2}$ & $\stackrel{n}{\sim}$ & 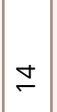 & 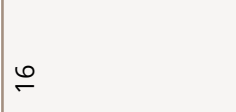 & $\stackrel{\sim}{ }$ & 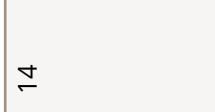 & $\simeq$ & $\stackrel{\sim}{N}$ \\
\hline & 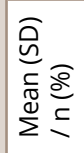 & $\begin{array}{l}\pi \\
1 \\
\\
0 \\
\infty \\
\infty\end{array}$ & $\begin{array}{l}\sigma \\
d \\
d \\
N \\
N\end{array}$ & $\begin{array}{l}0 \\
0 \\
\dot{0} \\
0 \\
0 \\
\dot{0} \\
ن\end{array}$ & 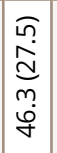 & 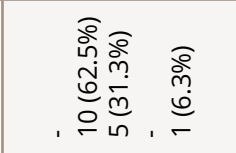 & 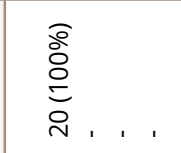 & 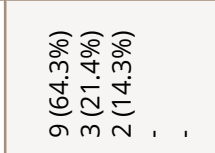 & 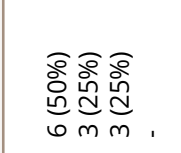 & 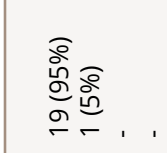 \\
\hline \multirow{2}{*}{ 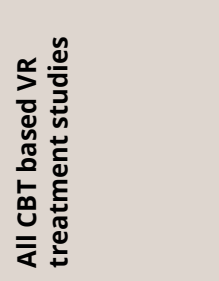 } & 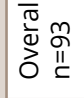 & $\infty$ & $\infty$ & $m$ & R & $\curvearrowright$ & ñ & $\bar{\kappa}$ & กิ & m \\
\hline & 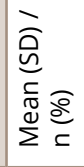 & 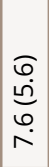 & $\begin{array}{l}\tilde{n} \\
\tilde{n} \\
\hat{n} \\
\text { in }\end{array}$ & 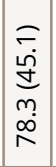 & $\begin{array}{l}\widehat{a} \\
\stackrel{d}{d} \\
d \\
\tilde{n} \\
\end{array}$ & 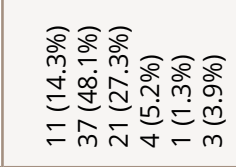 & 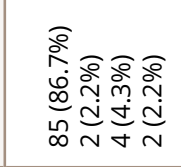 & 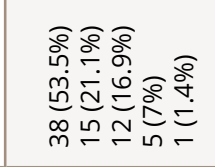 & 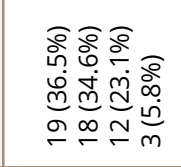 & 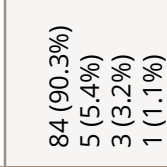 \\
\hline 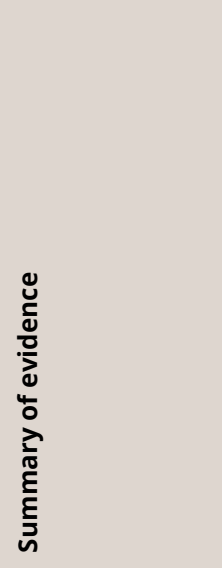 & 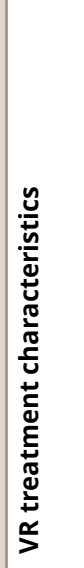 & 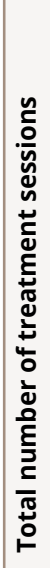 & 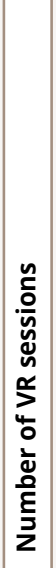 & 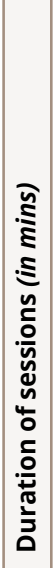 & 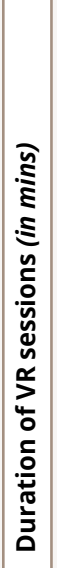 & 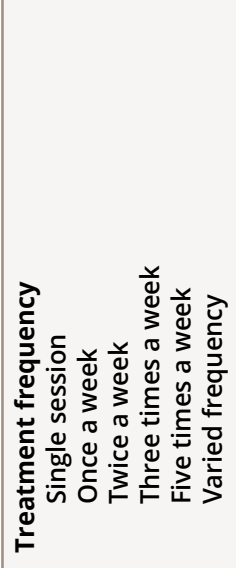 & 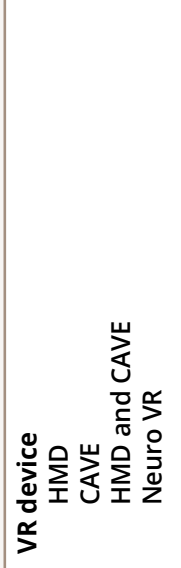 & 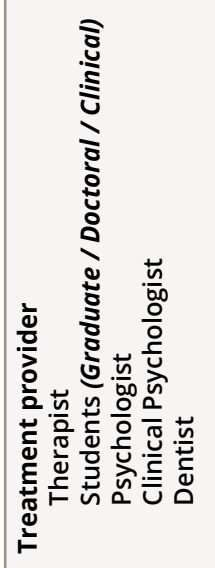 & 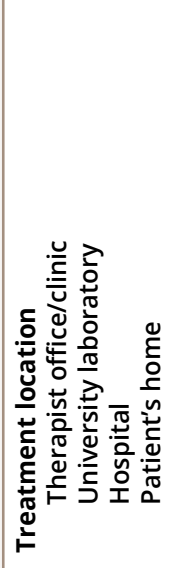 & 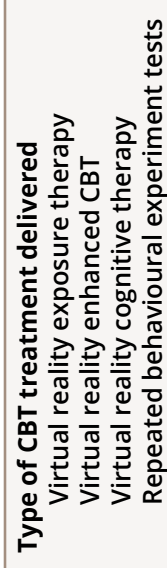 \\
\hline
\end{tabular}


Table 3. Summary of the study aims (Key* studies included in the analysis of the second aim)

\begin{tabular}{|c|c|c|c|c|}
\hline Aim $(n=93)$ & $\begin{array}{l}\text { Studies that } \\
\text { have found VR } \\
\text { treatments to be } \\
\text { effective }(n=46)\end{array}$ & $\begin{array}{l}\text { Studies that } \\
\text { have found VR } \\
\text { treatments } \\
\text { not effective in } \\
\text { comparison to } \\
\text { control groups } \\
(n=3)\end{array}$ & $\begin{array}{l}\text { Studies that have } \\
\text { found no significant } \\
\text { difference between } \\
\text { VR treatments and } \\
\text { control groups } \\
(n=13)\end{array}$ & $\begin{array}{l}\text { Studies that } \\
\text { have not focused } \\
\text { on treatment } \\
\text { effectiveness } \\
(n=31)\end{array}$ \\
\hline $\begin{array}{l}\text { *Effectiveness of VR treatment with a } \\
\text { specific patient population }(n=20)\end{array}$ & $23,28-46$ & No studies & No studies & Not applicable \\
\hline $\begin{array}{l}\text { *Effectiveness of VR treatment in } \\
\text { comparison to waiting list }(n=8)\end{array}$ & $47-53$ & No studies & 54 & Not applicable \\
\hline $\begin{array}{l}\text { Importance of presence } \\
\text { in VR treatment }(n=3)\end{array}$ & Not applicable & Not applicable & Not applicable & $55-57$ \\
\hline $\begin{array}{l}\text { Cost-effectiveness of VR treatment } \\
(n=1)\end{array}$ & Not applicable & Not applicable & Not applicable & 6 \\
\hline $\begin{array}{l}\text { *Effectiveness of VR treatment in } \\
\text { comparison to 'traditional' treatment } \\
\text { methods }(n=34)\end{array}$ & $58-77$ & $78-80$ & $22,81-91$ & Not applicable \\
\hline $\begin{array}{l}\text { Whether VR treatment is enhanced } \\
\text { with additional variables }(n=21)\end{array}$ & Not applicable & Not applicable & Not applicable & $92-112$ \\
\hline $\begin{array}{l}\text { Patient preference and acceptability } \\
(n=2)\end{array}$ & Not applicable & Not applicable & Not applicable & 113,114 \\
\hline $\begin{array}{l}\text { Feasibility of VR treatment with cheap } \\
\text { consumer hardware }(n=1)\end{array}$ & Not applicable & Not applicable & Not applicable & 115 \\
\hline $\begin{array}{l}\text { The ability to conduct remote therapy } \\
\text { using VR technology }(n=3)\end{array}$ & Not applicable & Not applicable & Not applicable & $116-118$ \\
\hline
\end{tabular}

provide an overview of all the aims $(n=93)$ then it will specifically focus on the subgroup of studies that aimed to investigate treatment effectiveness ( $n=62$ ).

The aim of the papers correlated with the year of publication, demonstrating that earlier studies tended to focus on assessing the efficacy of VR treatments, whereas later studies aimed to assess the use of cheaper technology and remote treatment delivery. For a summary of the study aims, please see Table 3 .

\section{Efficacy of VR treatment within}

\section{a specific patient population}

Of the 20 studies that used a repeated measures design to investigate the efficacy of VR treatment with a specific patient population, all considered VR to be an effective treatment for anxiety-related disorders [119-121], substance disorders [31] and eating disorders [122]. For instance, a cohort study comprising 20 combatrelated PTSD patients reported post-intervention, that following VRET, $80 \%$ of the patients no longer met the criteria for PTSD [23]. Another cohort study with 48 nicotine-dependent adults reported that VR cue exposure treatment reduced the patients' cigarette cravings [32]. Riva et al. (2002) [122] also used a cohort design with 57 obese and binge eating disorder patients and reported that VR-enhanced CBT, improved patients' body satisfaction.

A breakdown of the treatment characteristics in studies that found VR treatment effective within a specific population, can be found in Table 2 . These studies generally consisted of a small sample size $(M=25.4, S D=26.8, n=20)$. The treatments involved 
a mean of nine sessions, and VR was used in seven of these sessions. The treatment was delivered once a week for a mean duration of 54 minutes.

\section{Efficacy of VR treatment by comparison with waiting list}

Similar to studies that investigated the effectiveness of VR treatment within a specific patient population, the majority of the studies reported VR treatments to be relatively more effective than waiting list controls $(n=7)$. A controlled clinical trial with 23 arachnophobia patients, reported that VRET was effective in treating this phobia. Eighty-three per cent of the patients in the VRET group showed a significant clinical improvement by comparison with no improvement in the waiting list group [49]. An RCT, with 116 psychotic disorder patients, found that VRCBT did not increase the length of time patients spent with other people, however, it did significantly improve patients' momentary paranoid ideation and anxiety. These improvements were maintained six months after completion of follow-up treatments [26].

Only one RCT that had 32 general anxiety disorder patients, reported that a single session of VRET was not significantly effective by comparison with the waiting list group [54].

The fourth column of Table 2 presents a breakdown of treatment characteristics in the studies that found VR treatment to be more effective than a waiting list

Table 4. Summary VR treatment effectiveness in comparison to other 'traditional' treatments

\begin{tabular}{|c|c|c|c|}
\hline $\begin{array}{l}\text { Effectiveness of VR treatment in } \\
\text { comparison to 'traditional' treatment } \\
\text { methods }(n=34)\end{array}$ & $\begin{array}{l}\text { VR treatment less } \\
\text { efficacious }(n=3)\end{array}$ & $\begin{array}{l}\text { VR treatment equally } \\
\text { efficacious }(n=12)\end{array}$ & $\begin{array}{l}\text { VR treatment more } \\
\text { efficacious }(n=19)\end{array}$ \\
\hline In-vivo exposure $(\mathrm{n}=11)$ & 78,79 & $19,22,81,84,86,90$ & $69,71,123$ \\
\hline CBT $(n=7)$ & - & 85,124 & $65,67,68,72,125$ \\
\hline Imaginal exposure $(n=3)$ & - & 126,127 & 74 \\
\hline Psychoeducation $(n=2)$ & - & - & 128,129 \\
\hline Treatment as usual $(\mathrm{n}=2)$ & - & - & 27,63 \\
\hline Bibliotherapy $(n=1)$ & - & - & 110 \\
\hline Prolonged exposure $(n=1)$ & 80 & - & - \\
\hline Integrated psychological therapy $(n=1)$ & - & - & 77 \\
\hline Nicotine replacement $(n=1)$ & - & - & 59 \\
\hline Information pamphlet $(\mathrm{n}=1)$ & - & - & 75 \\
\hline Control exposure $(n=1)$ & - & 88 & - \\
\hline Computer-aided exposure $(\mathrm{n}=1)$ & - & 131 & - \\
\hline Relaxation group $(n=1)$ & - & - & 64 \\
\hline
\end{tabular}


control group. The treatment characteristics were similar to those studies that were investigating the effectiveness of VR within a specific population. For instance, studies were delivered across a mean of 10 sessions, and seven of these involved VR.

\section{Effectiveness of VR treatment by comparison}

\section{with "traditional' treatment methods}

The majority of the studies in this review aimed to identify the effectiveness of VR treatments by comparison with 'traditional' treatment methods. Thirty-one out of the 34 studies (91.2\%) considered VR treatments to be equally or more efficacious than traditional treatment methods. See Table 4 for a summary of VR treatment effectiveness by comparison with other 'traditional' treatments.

Three RCTs considered VR treatments to be less efficacious than 'traditional' treatment methods. Two compared the effectiveness of VRET with in vivo exposure treatment, where patients are physically exposed to the feared stimuli. Meyerbroeker et al. (2013) [79] randomized 55 agoraphobia patients and found that in-vivo exposure decreased patients' panic severity more than VRET. Similarly, Kampmann et al. (2016) [78] randomized 60 patients with a social anxiety disorder and noted that in-vivo exposure decreased patients' social anxiety symptoms. Another RCT compared the effectiveness of VRET with prolonged exposure in 162 combat-related PTSD patients. Follow-ups at three and six months reported that prolonged exposure had significantly reduced more PTSD symptoms than VRET [80].

The number of studies that reported negative results is minimal $(n=3)$. Despite the small number of negative results, studies between effective and ineffective VR treatments were compared using a t-test. Studies which found VR treatment to be inferior to traditional methods had a larger sample size $(M=92.3)$ than those which considered VR treatments to be superior $(M=48.8)$. However, this difference was not significant ( $T=-1.8, D F=20, P=0.09$ ).

Data were also collected in relation to participant drop-out rates. The patients' reasons for dropping out of VR treatments included VR exposure not arousing the anxiety that is necessary for desensitization [76], VR causing motion sickness and conflicts with patients' diaries [130]. The patients' reasons for dropping out of 'traditional' treatments included not wanting in-vivo exposure [71], not being satisfied with the treatment allocation and wanting to pay for VR therapy [69]. Studies which found VR treatments more effective than 'traditional' treatments reported significantly lower VR drop-out rates $(M=15.1 \%)$ than treatments which regarded 'traditional' treatments as superior to VR treatments $(M=39 \%)(T=-2.4, D F=13, P=0.04)$.

Therefore, patient drop-out rates were a variable in the success of VR treatment. The other treatment variables, such as the number and duration of the sessions, were very similar across the two outcomes. Please see Table 2, Column 6 for comparisons between the variables.

\section{DISCUSSION}

Main findings

VR has mainly been used in the treatment of anxietyrelated disorders, and treatment has usually taken the form of exposure therapies. VR has generally been used as a component in a more extensive treatment protocol. On average, patients were offered eight sessions of therapy, and six of these sessions involved VR technology. The sessions were usually delivered once a week for an average of 53 minutes.

Even though the overall quality of the evidence is weak, VR treatments seemed to perform comparably in terms of efficacy with 'traditional' face-to-face treatments. Treatment characteristics, such as the number and duration of sessions, were very similar between studies that regarded VR treatment as effective and those that found it not to be effective. However, patient drop-out rates were significantly lower in studies that considered VR treatment to be effective by comparison with those that found it ineffective.

\section{Comparison with literature}

This review is the first to investigate how VR has been used in CBT (a psychotherapeutic approach) to treat a variety of mental health disorders. Previous VR reviews have focused on providing a general overview of the field [8] or reported treatment outcomes for specific diagnoses [2].

Results from this review support the findings from previous reviews, that VR is an acceptable and promising therapeutic tool for mental health treatment [4]. It can be used to deliver cognitive rehabilitation, social skills training interventions and VR-assisted 
therapies for psychosis [5]. VRET is equally effective as in-vivo exposure for the treatment of anxietyrelated disorders [3].

However, regardless of the wide variety of CBT treatment techniques and applications, research into VR treatments still focuses primarily on treating anxiety-related disorders with exposure-based therapies [8, 132]. There is still limited research into different types of CBT therapies, e.g., group therapies, and limited research into applications for different diagnostic groups, e.g., patients with mood disorders [8, 133, 134].

In a recent review, Freeman et al. (2017) [8] highlighted evidence that drop-out rates may be lower with VR treatments. This review supports this finding; overall, fewer patients dropped out of VR treatments than 'traditional' treatments. However, similar to Freeman's review, as differences in drop-outs may have been due to the quality of face-to-face treatments, this review is also unable to make any firm conclusions regarding these differences, but it does highlight the importance of offering high-quality treatments in research studies.

\section{Strengths and Limitations}

This review is the first to collate data as to how CBT has been used in VR to treat mental health disorders. The shared treatment characteristics (e.g., eight sessions, once a week for approximately one hour) identified in this review, could potentially prevent researchers from wasting resources developing one-off interventions. Building on the shared treatment characteristics identified in this review, may potentially enable researchers to explore new VR treatment methods or explore VR treatments for under-researched diagnoses.

The treatment framework developed from this review (e.g., eight sessions, once a week for approximately one hour using an HMD) may have potential clinical implications. The lack of VR treatment guidelines could potentially have been a barrier to VR treatments entering mainstream clinical practice. Building on the treatment framework developed from this review, therapists or clinics may feel more confident to offer their patients CBT-based VR treatments.

The results from this review need to be understood within the context of its limitations. This review consisted of a high volume of papers, produced from original studies. Many authors used data across different studies, and some authors avoided referencing their data source. This has made the separation of the original studies from secondary analysis papers difficult. A significant amount of time was spent matching the papers, and studies were compared for similarities and differences. Therefore, although the potential risk of overrepresentation of some studies is minimal, this cannot be ruled out completely. However, as the results were mainly synthesized narratively, according to treatment characteristics and methods, this would have had a limited impact on the findings.

The second aim of this review was to report the shared characteristics of effective and ineffective CBT methods. Even though the review search criteria and strategy were extensive, this review may have been affected by publication bias. Negative results are less likely to have been published. This review only identified three recent studies that reported the inferiority of VR treatment. This may be an indicator of time-lag bias, where positive findings are published first and negative findings later. Therefore, the results section of this review, comparing the shared treatment characteristics of effective and ineffective CBT methods, should be interpreted with caution.

Furthermore, this review has only conducted causal associations but has not tested these associations in a formal manner, e.g., this review cannot conclude that reducing the number of sessions from eight to five will reduce treatment effectiveness. However, the analysis conducted in this review and the framework created, is based on the best available evidence, although future studies would be required to test the framework generated.

\section{CONCLUSIONS}

This review is the first to synthesize CBT treatment characteristics and methods used in VR to treat mental health disorders. The shared treatment characteristics of a total of eight treatment sessions, once a week for approximately an hour, could be used as a treatment template by future researchers. This could potentially prevent researchers from spending time and money developing their own one-off interventions. Furthermore, it may possibly enable researchers to explore new VR treatment methods or explore VR treatments for under-researched diagnoses. 
Acknowledgements: The authors wish to acknowledge the Faculty Liaison Librarian, Paula Funnell for assisting with the search strategy of this study, The East London Foundation Trust whose funding supported this research and the researchers at the Unit for Social and Community Psychiatry, who provided feedback on an early draft of this paper.

Author Contributions: Merve Dilgul: conceptualization, methodology, formal analysis, writing-review and editing; Jasmine J. Martinez: formal analysis; Neelan Laxhman: formal analysis; Stefan Priebe: conceptualization, methodology, supervision; Victoria Bird: conceptualization, methodology, writing-review and editing, supervision.

Funding: The East London NHS Foundation Trust has funded this study as part of a PhD Project. The funder of the study had no role in study design, data collection, data analysis, data interpretation or writing of the report. The corresponding author had full access to all the data in the study and took the final decision to submit for publication.

Conflict of Interest: The authors report no conflict of interest.

\section{Correspondence to:}

\section{Merve Dilgul}

m.dilgul@qmul.ac.uk

\section{References}

1. Maples-Keller JL, Bunnell BE, Kim SJ, Rothbaum BO. The Use of Virtual Reality Technology in the Treatment of Anxiety and Other Psychiatric Disorders. Harv Rev Psychiatry. 2017 May/Jun;25(3):103113. doi: 10.1097/HRP.0000000000000138. PMID: 28475502; PMCID: PMC5421394.

2. Zeng N, Pope Z, Lee JE, Gao Z. Virtual Reality Exercise for Anxiety and Depression: A Preliminary Review of Current Research in an Emerging Field. J Clin Med. 2018 Mar 4;7(3):42. doi: 10.3390/jcm7030042. PMID: 29510528; PMCID: PMC5867568.

3. Carl E, Stein AT, Levihn-Coon A, Pogue JR, Rothbaum B, Emmelkamp $P$, Asmundson GJG, Carlbring P, Powers MB. Virtual reality exposure therapy for anxiety and related disorders: A meta-analysis of randomized controlled trials. J Anxiety Disord. 2019 Jan;61:27-36. doi: 10.1016/j.janxdis.2018.08.003. Epub 2018 Aug 10. PMID: 30287083.

4. Clus D, Larsen ME, Lemey C, Berrouiguet S. The Use of Virtual Reality in Patients with Eating Disorders: Systematic Review. J Med Internet Res. 2018 Apr 27;20(4):e157. doi: 10.2196/jmir.7898. PMID: 29703715; PMCID: PMC5948410.

5. Rus-Calafell M, Garety P, Sason E, Craig TJK, Valmaggia LR. Virtual reality in the assessment and treatment of psychosis: a systematic review of its utility, acceptability and effectiveness. Psychol Med. 2018 Feb;48(3):362-391. doi: 10.1017/S0033291717001945. Epub 2017 Jul 24. PMID: 28735593.

6. Wood DP, Murphy J, McLay R, Koffman R, Spira J, Obrecht RE, Pyne J, Wiederhold BK. Cost effectiveness of virtual reality graded exposure therapy with physiological monitoring for the treatment of combat related post traumatic stress disorder. Stud Health Technol Inform. 2009;144:223-9. PMID: 19592768.

7. Baños RM, Guillen V, Quero S, Garcia-Palacios A, Alcaniz M, Botella C. A virtual reality system for the treatment of stressrelated disorders: A preliminary analysis of efficacy compared to a standard cognitive behavioral program. International Journal of Human-Computer Studies. 2011 Aug 1;69(9):602-13. doi:10.1016/j. ijhcs.2011.06.002

8. Freeman D, Reeve S, Robinson A, Ehlers A, Clark D, Spanlang $B$, Slater M. Virtual reality in the assessment, understanding, and treatment of mental health disorders. Psychol Med. 2017 Oct;47(14):2393-2400. doi: 10.1017/S003329171700040X. Epub 2017 Mar 22. PMID: 28325167; PMCID: PMC5964457.

9. Oxford English Dictionary [Internet]. Oxford University Press. 2020. [cited 2020 August 10]. Available from: https://www.oed.com/.

10. Riva G. Virtual reality in psychotherapy: review. Cyberpsychol Behav. 2005 Jun;8(3):220-30; discussion 231-40. doi: 10.1089/ cpb.2005.8.220. PMID: 15971972.

11. Butler AC, Chapman JE, Forman EM, Beck AT. The empirical status of cognitive-behavioral therapy: a review of meta-analyses. Clin Psychol Rev. 2006 Jan;26(1):17-31. doi: 10.1016/j.cpr.2005.07.003. Epub 2005 Sep 30. PMID: 16199119.

12. Beck AT. Cognitive therapy and the emotional disorders. New York: International Universities Press; 1976. 356 p..

13. Fenn K, Byrne M. The key principles of cognitive behavioural therapy. InnovAiT Educ Inspir Gen Pract. 2013;6(9):579-85. doi:10.1177/1755738012471029.

14. Davies KS. Formulating the Evidence Based Practice Question: A Review of the Frameworks. EBLIP [Internet]. 2011;6(2):75-80 [cited 2020 August 10]. Available from: https://journals.library.ualberta. ca/eblip/index.php/EBLIP/article/view/9741

15. NHS choices [Internet]. Cognitive behavioural therapy (CBT). [modified 2019 July 16; cited 2020 August 10] Available from: https://www.nhs.uk/conditions/cognitivebehavioural-therapy-cbt/.

16. Barfield W, Furness TA, editors. Virtual Environments and Advanced Interface Design. USA: Oxford University Press; 1995. 600 p.

17. Cruz-Neira C, Sandin D, DeFanti T. Surround-screen projectionbased virtual reality: the design and implementation of the CAVE. In: Proceedings of the 20st Annual Conference on Computer Graphics and Interactive Techniques, SIGGRAPH. 1993. doi:10.1145/166117.166134.

18. Falconer CJ, Rovira A, King JA, Gilbert P, Antley A, Fearon P, Ralph $\mathrm{N}$, Slater M, Brewin CR. Embodying self-compassion within virtual reality and its effects on patients with depression. BJPsych Open. 2016 Feb 15;2(1):74-80. doi: 10.1192/bjpo.bp.115.002147. PMID: 27703757; PMCID: PMC4995586.

19. Wallach HS, Safir MP, Bar-Zvi M. Virtual reality cognitive behavior therapy for public speaking anxiety: a randomized clinical trial. Behav Modif. 2009 May;33(3):314-38. doi: 10.1177/0145445509331926. Epub 2009 Mar 25. PMID: 19321811.

20. Popay J, Roberts H, Sowden A, et al. Guidance on the Conduct of Narrative Synthesis in Systematic Reviews. A Prod from 
ESRC Methods Program. 2006;211-9. doi:10.1111/j.1523536x.1995tb00261.x.

21. Effective Public Health Practice Project. Quality assessment tool for quantitative studies [Internet]. Eff Public Heal Pract Proj. 2010;2-5 [cited 2020 August 10]. Available from: https://www. ephpp.ca/quality-assessment-tool-for-quantitative-studies/

22. Michaliszyn D, Marchand A, Bouchard S, Martel MO, PoirierBisson J. A randomized, controlled clinical trial of in virtuo and in vivo exposure for spider phobia. Cyberpsychol Behav Soc Netw. 2010 Dec;13(6):689-95. doi: 10.1089/cyber.2009.0277. Epub 2010 May 3. PMID: 21142994.

23. Rizzo AS, Difede J, Rothbaum BO, Reger G, Spitalnick J, Cukor J, McLay R. Development and early evaluation of the Virtual Iraq/ Afghanistan exposure therapy system for combat-related PTSD. Ann N Y Acad Sci. 2010 Oct;1208:114-25. doi: 10.1111/j.17496632.2010.05755.x. PMID: 20955333.

24. Riva G, Bacchetta M, Baruffi M, Molinari E. Virtual-reality-based multidimensional therapy for the treatment of body image disturbances in binge eating disorders: a preliminary controlled study. IEEE Trans Inf Technol Biomed. 2002 Sep;6(3):224-34. doi: 10.1109/titb.2002.802372. PMID: 12381039.

25. Pot-Kolder RMCA, Geraets CNW, Veling W, van Beilen M, Staring ABP, Gijsman HJ, Delespaul PAEG, van der Gaag M. Virtual-realitybased cognitive behavioural therapy versus waiting list control for paranoid ideation and social avoidance in patients with psychotic disorders: a single-blind randomised controlled trial. Lancet Psychiatry. 2018 Mar;5(3):217-226. doi: 10.1016/S22150366(18)30053-1. Epub 2018 Feb 9. PMID: 29429948.

26. Pot-Kolder RMCA, Geraets CNW, Veling W, van Beilen M, Staring ABP, Gijsman HJ, Delespaul PAEG, van der Gaag M. Virtual-realitybased cognitive behavioural therapy versus waiting list control for paranoid ideation and social avoidance in patients with psychotic disorders: a single-blind randomised controlled trial. Lancet Psychiatry. 2018 Mar;5(3):217-226. doi: 10.1016/S22150366(18)30053-1. Epub 2018 Feb 9. PMID: 29429948.

27. Freeman D, Haselton $P$, Freeman J, Spanlang B, Kishore $S$, Albery E, Denne M, Brown P, Slater M, Nickless A. Automated psychological therapy using immersive virtual reality for treatment of fear of heights: a single-blind, parallel-group, randomised controlled trial. Lancet Psychiatry. 2018 Aug;5(8):625632. doi: 10.1016/S2215-0366(18)30226-8. Epub 2018 Jul 11. PMID: 30007519; PMCID: PMC6063994.

28. Anderson PL, Zimand E, Hodges LF, Rothbaum BO. Cognitive behavioral therapy for public-speaking anxiety using virtual reality for exposure. Depress Anxiety. 2005;22(3):156-8. doi: 10.1002/ da.20090. PMID: 16231290.

29. Malbos E, Mestre DR, Note ID, Gellato C. Virtual reality and claustrophobia: multiple components therapy involving game editor virtual environments exposure. Cyberpsychol Behav. 2008 Dec;11(6):695-7. doi: 10.1089/cpb.2007.0246. PMID: 18954278.

30. McLay R, Ram V, Murphy J, Spira J, Wood DP, Wiederhold MD, Wiederhold BK, Johnston S, Reeves D. Effect of virtual reality PTSD treatment on mood and neurocognitive outcomes. Cyberpsychol Behav Soc Netw. 2014 Jul;17(7):439-46. doi: 10.1089/cyber.2013.0383. Epub 2014 Mar 17. PMID: 24635120.

31. Pericot-Valverde I, García-Rodríguez O, Gutiérrez-Maldonado J, Secades-Villa R. Individual variables related to craving reduction in cue exposure treatment. Addict Behav. 2015 Oct;49:59-63. doi: 10.1016/j.addbeh.2015.05.013. Epub 2015 May 23. PMID: 26047836.
32. Pericot-Valverde I, Secades-Villa R, Gutiérrez-Maldonado J, García-Rodríguez O. Effects of systematic cue exposure through virtual reality on cigarette craving. Nicotine Tob Res. 2014 Nov;16(11):1470-7. doi: 10.1093/ntr/ntu104. Epub 2014 Jun 23. PMID: 24962558; PMCID: PMC4342674.

33. Riva G, Bacchetta M, Baruffi M, Cirillo G, Molinari E. Virtual reality environment for body image modification: A multidimensional therapy for the treatment of body image in obesity and related pathologies. CyberPsychology \& Behavior. 2000 Jun 1;3(3):421-31. doi:10.1089/10949310050078887

34. Rothbaum BO, Hodges LF, Ready D, Graap K, Alarcon RD. Virtual reality exposure therapy for Vietnam veterans with posttraumatic stress disorder. J Clin Psychiatry. 2001 Aug;62(8):617-22. doi: 10.4088/jcp.v62n0808. PMID: 11561934.

35. Wald J. Efficacy of virtual reality exposure therapy for driving phobia: A multiple baseline across-subjects design. Behavior Therapy. 2004 Jun 1;35(3):621-35. doi:10.1016/S00057894(04)80035-2

36. Walshe DG, Lewis EJ, Kim SI, O'Sullivan K, Wiederhold BK. Exploring the use of computer games and virtual reality in exposure therapy for fear of driving following a motor vehicle accident. Cyberpsychol Behav. 2003 Jun;6(3):329-34. doi: 10.1089/109493103322011641. PMID: 12855091.

37. Wiederhold BK, Jang DP, Kim SI, Wiederhold MD. Physiological monitoring as an objective tool in virtual reality therapy. Cyberpsychol Behav. 2002 Feb;5(1):77-82. doi: 10.1089/109493102753685908. PMID: 11990977.

38. Znaidi F, Viaud-Delmon I, Jouvent R. Generic virtual reality treatment applied to space-related phobias. Annu Rev CyberTher Telemed. 2006 Jun 1;4:175-9.

39. Baños RM, Botella C, Perpiñá C, Alcañiz M, Lozano JA, Osma J, Gallardo M. Virtual reality treatment of flying phobia. IEEE Trans Inf Technol Biomed. 2002 Sep;6(3):206-12. doi: 10.1109/ titb.2002.802380. PMID: 12381036.

40. Beidel DC, Frueh BC, Neer SM, Lejuez CW. The efficacy of Trauma Management Therapy: A controlled pilot investigation of a three-week intensive outpatient program for combat-related PTSD. J Anxiety Disord. 2017 Aug;50:23-32. doi: 10.1016/j. janxdis.2017.05.001. Epub 2017 May 11. PMID: 28545005.

41. Botella C, Baños RM, Villa H, Perpiñá C, García-Palacios A. Virtual reality in the treatment of claustrophobic fear: A controlled, multiple-baseline design. Behav Ther. 2000 Jun 1;31(3):583-95. doi:10.1016/S0005-7894(00)80032-5

42. Botella C, Osma J, Garcia-Palacios A, Quero S, Baños RM. Treatment of flying phobia using virtual reality: data from a 1-year follow-up using a multiple baseline design. Clin Psychol Psychother. 2004 Sep;11(5):311-23. doi:10.1002/cpp.404

43. Coelho CM, Santos JA, Silvério J, Silva CF. Virtual reality and acrophobia: one-year follow-up and case study. Cyberpsychol Behav. 2006 Jun;9(3):336-41. doi: 10.1089/cpb.2006.9.336. PMID: 16780401.

44. Côté S, Bouchard S. Documenting the efficacy of virtual reality exposure with psychophysiological and information processing measures. Appl Psychophysiol Biofeedback. 2005 Sep;30(3):21732. doi: 10.1007/s10484-005-6379-x. PMID: 16167187.

45. Grillon H, Riquier F, Herbelin B, Thalmann D. Virtual reality as therapeutic tool in the confines of social anxiety disorder treatment. Int J Disabil Hum Dev. 2006;5(ARTICLE):243-50. doi:10.1515/IJDHD.2006.5.3.243.

46. Kahan M, Tanzer J, Darvin D, Borer F. Virtual reality-assisted cognitive-behavioral treatment for fear of flying: Acute treatment 
and follow-up. Cyberpsychol Behav. 2000 Jun; 1;3(3):387-92. doi:10.1089/10949310050078832

47. Bullinger AH, Angehrn I, Wiederhold BK, Mueller-Spahn F, Mager R. Treating acrophobia in a virtual environment. Annu Rev cybertherapy Telemed. 2005 Jul;3:93-100.

48. Difede J, Cukor J, Jayasinghe N, Patt I, Jedel S, Spielman L, Giosan C, Hoffman HG. Virtual reality exposure therapy for the treatment of posttraumatic stress disorder following September 11, 2001. J Clin Psychiatry. 2007 Nov;68(11):1639-47. PMID: 18052556.

49. Garcia-Palacios A, Hoffman H, Carlin A, Furness TA 3rd, Botella C. Virtual reality in the treatment of spider phobia: a controlled study. Behav Res Ther. 2002 Sep;40(9):983-93. doi: 10.1016/s00057967(01)00068-7. PMID: 12296495.

50. Harris SR, Kemmerling RL, North MM. Brief virtual reality therapy for public speaking anxiety. Cyberpsychol Behav. 2002 Dec;5(6):543-50. doi: 10.1089/109493102321018187. PMID: 12556117.

51. Loucks L, Yasinski C, Norrholm SD, Maples-Keller J, Post L, Zwiebach L, Fiorillo D, Goodlin M, Jovanovic T, Rizzo AA, Rothbaum BO. You can do that?!: Feasibility of virtual reality exposure therapy in the treatment of PTSD due to military sexual trauma. J Anxiety Disord. 2019 Jan;61:55-63. doi: 10.1016/j. janxdis.2018.06.004. Epub 2018 Jun 18. PMID: 30005843.

52. Pot-Kolder RMCA, Geraets CNW, Veling W, van Beilen M, Staring ABP, Gijsman HJ, Delespaul PAEG, van der Gaag M. Virtual-realitybased cognitive behavioural therapy versus waiting list control for paranoid ideation and social avoidance in patients with psychotic disorders: a single-blind randomised controlled trial. Lancet Psychiatry. 2018 Mar;5(3):217-226. doi: 10.1016/S22150366(18)30053-1. Epub 2018 Feb 9. PMID: 29429948.

53. Rothbaum BO, Hodges L, Smith S, Lee JH, Price L. A controlled study of virtual reality exposure therapy for the fear of flying. J Consult Clin Psychol. 2000 Dec;68(6):1020-6. doi: 10.1037//0022006x.68.6.1020. PMID: 11142535.

54. Moldovan R, David D. One session treatment of cognitive and behavioral therapy and virtual reality for social and specific phobias. Preliminary results from a randomized clinical trial. Journal of Evidence-Based Psychotherapies [Internet]. 2014;14(1):67-83. [cited 2020 August 10]. Available from: https:// www.researchgate.net/publication/267842953

55. Krijn M, Emmelkamp PM, Biemond R, de Wilde de Ligny C, Schuemie MJ, van der Mast CA. Treatment of acrophobia in virtual reality: the role of immersion and presence. Behav Res Ther. 2004;42(2):229-39. doi: 10.1016/S0005-7967(03)00139-6. PMID: 14975783.

56. Meyerbröker K, Morina N, Kerkhof G, Emmelkamp PM. Virtual reality exposure treatment of agoraphobia: a comparison of computer automatic virtual environment and headmounted display. Stud Health Technol Inform. 2011;167:51-6. PMID: 21685641.

57. Price $M$, Anderson $P$. The role of presence in virtual reality exposure therapy. J Anxiety Disord. 2007;21(5):742-51. doi: 10.1016/j.janxdis.2006.11.002. Epub 2006 Dec 4. PMID: 17145164; PMCID: PMC3670421.

58. Beidel DC, Frueh BC, Neer SM, Bowers CA, Trachik B, Uhde TW, Grubaugh A. Trauma management therapy with virtual-reality augmented exposure therapy for combat-related PTSD: A randomized controlled trial. J Anxiety Disord. 2019 Jan;61:64-74. doi: 10.1016/j.janxdis.2017.08.005. Epub 2017 Aug 23. PMID: 28865911.

59. Bordnick PS, Traylor AC, Carter BL, Graap KM. A Feasibility Study of Virtual Reality-Based Coping Skills Training for
Nicotine Dependence. Res Soc Work Pract. 2012 May;22(3):293300. doi: 10.1177/1049731511426880. PMID: 25484549; PMCID: PMC4254682.

60. Lima J, McCabe-Bennett H, Antony MM. Treatment of Storm Fears Using Virtual Reality and Progressive Muscle Relaxation. Behav Cogn Psychother. 2018 Mar;46(2):251-256. doi: 10.1017/ S1352465817000674. Epub 2017 Oct 30. PMID: 29081326.

61. Maltby N, Kirsch I, Mayers M, Allen GJ. Virtual reality exposure therapy for the treatment of fear of flying: a controlled investigation. J Consult Clin Psychol. 2002 Oct;70(5):1112-8. doi: 10.1037//0022-006x.70.5.1112. PMID: 12362961.

62. Marco JH, Perpiñá C, Botella C. Effectiveness of cognitive behavioral therapy supported by virtual reality in the treatment of body image in eating disorders: one year followup. Psychiatry Res. 2013 Oct 30;209(3):619-25. doi: 10.1016/j. psychres.2013.02.023. Epub 2013 Mar 15. PMID: 23499231.

63. McLay RN, Wood DP, Webb-Murphy JA, Spira JL, Wiederhold MD, Pyne JM, Wiederhold BK. A randomized, controlled trial of virtual reality-graded exposure therapy for post-traumatic stress disorder in active duty service members with combat-related post-traumatic stress disorder. Cyberpsychol Behav Soc Netw. 2011 Apr;14(4):223-9. doi: 10.1089/cyber.2011.0003. Epub 2011 Feb 20. PMID: 21332375.

64. Mühlberger A, Herrmann MJ, Wiedemann GC, Ellgring H, Pauli P. Repeated exposure of flight phobics to flights in virtual reality. Behav Res Ther. 2001 Sep;39(9):1033-50. doi: 10.1016/s00057967(00)00076-0. PMID: 11520010.

65. Riva G, Bacchetta M, Baruffi M, Molinari E. Virtual-reality-based multidimensional therapy for the treatment of body image disturbances in binge eating disorders: a preliminary controlled study. IEEE Trans Inf Technol Biomed. 2002 Sep;6(3):224-34. doi: 10.1109/titb.2002.802372. PMID: 12381039.

66. Ferrer-García M, Gutiérrez-Maldonado J, Pla-Sanjuanelo J, Vilalta-Abella F, Riva G, Clerici M, Ribas-Sabaté J, Andreu-Gracia A, Fernandez-Aranda F, Forcano L, Riesco N, Sánchez I, EscandónNagel N, Gomez-Tricio O, Tena V, Dakanalis A. A Randomised Controlled Comparison of Second-Level Treatment Approaches for Treatment-Resistant Adults with Bulimia Nervosa and Binge Eating Disorder: Assessing the Benefits of Virtual Reality Cue Exposure Therapy. Eur Eat Disord Rev. 2017 Nov;25(6):479-490. doi: 10.1002/erv.2538. Epub 2017 Aug 14. PMID: 28804985.

67. Riva G, Bacchetta M, Cesa G, Conti S, Molinari E. The use of VR in the treatment of eating disorders. Stud Health Technol Inform. 2004;99:121-63. doi:10.3233/978-1-60750-943-1-121. PMID: 15295149.

68. Vincelli F, Anolli L, Bouchard S, Wiederhold BK, Zurloni V, Riva G. Experiential cognitive therapy in the treatment of panic disorders with agoraphobia: a controlled study. Cyberpsychol Behav. 2003 Jun;6(3):321-8. doi: 10.1089/109493103322011632. PMID: 12855090.

69. Wiederhold BK, Gevirtz RN, Spira JL. Virtual reality exposure therapy vs. imagery desensitization therapy in the treatment of flying phobia. In: Riva G, Galimberti C, editors. Towards cyberpsychology. Amsterdam: IOSpress; 2001. p. 254-72.

70. Botella C, Villa H, García Palacios A, Quero S, Baños RM, Alcaniz M. The use of VR in the treatment of panic disorders and agoraphobia. Stud Health Technol Inform. 2004;99:73-90. doi:10.3233/978-1-60750-943-1-73. PMID: 15295147.

71. Bouchard S, Dumoulin S, Robillard G, Guitard T, Klinger É, Forget $\mathrm{H}$, Loranger $\mathrm{C}$, Roucaut FX. Virtual reality compared with in vivoexposure in the treatment of social anxiety disorder: 
a three-arm randomised controlled trial. Br J Psychiatry. 2017 Apr;210(4):276-283. doi: 10.1192/bjp.bp.116.184234. Epub 2016 Dec 15. PMID: 27979818.

72. Cesa GL, Manzoni GM, Bacchetta M, Castelnuovo G, Conti S, Gaggioli A, Mantovani F, Molinari E, Cárdenas-López G, Riva G. Virtual reality for enhancing the cognitive behavioral treatment of obesity with binge eating disorder: randomized controlled study with one-year follow-up. J Med Internet Res. 2013 Jun 12;15(6):e113. doi: 10.2196/jmir.2441. PMID: 23759286; PMCID: PMC3713949.

73. Freeman D, Haselton P, Freeman J, Spanlang B, Kishore $S$, Albery E, Denne M, Brown P, Slater M, Nickless A. Automated psychological therapy using immersive virtual reality for treatment of fear of heights: a single-blind, parallel-group, randomised controlled trial. Lancet Psychiatry. 2018 Aug;5(8):625632. doi: 10.1016/S2215-0366(18)30226-8. Epub 2018 Jul 11. PMID: 30007519; PMCID: PMC6063994.

74. Gamito P, Oliveira J, Morais D, Oliveira S, Duarte N, Saraiva T, Pombal M, Rosa P. Virtual Reality Therapy Controlled Study for War Veterans with PTSD. Preliminary Results. Stud Health Technol Inform. 2009;144:269-72. PMID: 19592779.

75. Gujjar KR, van Wijk A, Sharma R, de Jongh A. Virtual Reality Exposure Therapy for the Treatment of Dental Phobia: $A$ Controlled Feasibility Study. Behav Cogn Psychother. 2018 May;46(3):367-373. doi: 10.1017/S1352465817000534. Epub 2017 Sep 14. PMID: 28903790.

76. Krijn M, Emmelkamp PM, Olafsson RP, Bouwman $M$, van Gerwen LJ, Spinhoven P, Schuemie MJ, van der Mast CA. Fear of flying treatment methods: virtual reality exposure vs. cognitive behavioral therapy. Aviat Space Environ Med. 2007 Feb;78(2):121-8. PMID: 17310883.

77. La Paglia F, La Cascia C, Rizzo R, Sideli L, Francomano A, La Barbera D. Cognitive rehabilitation of schizophrenia through NeuroVr training. Annual Review of Cybertherapy and Telemedicine 2013: Positive Technology and Health Engagement for Healthy Living and Active Ageing. Stud Health Technol Inform. 2013;191:158-62. doi:10.3233/978-1-61499-282-0-158. PMID: 23792865.

78. Kampmann IL, Emmelkamp PM, Hartanto D, Brinkman WP, Zijlstra BJ, Morina N. Exposure to virtual social interactions in the treatment of social anxiety disorder: A randomized controlled trial. Behav Res Ther. 2016 Feb;77:147-56. doi: 10.1016/j. brat.2015.12.016. Epub 2015 Dec 29. PMID: 26752328.

79. Meyerbroeker K, Morina N, Kerkhof GA, Emmelkamp PM. Virtual reality exposure therapy does not provide any additional value in agoraphobic patients: a randomized controlled trial. Psychother Psychosom. 2013;82(3):170-6. doi: 10.1159/000342715. Epub 2013 Mar 27. PMID: 23548832.

80. Reger GM, Koenen-Woods P, Zetocha K, Smolenski DJ, Holloway KM, Rothbaum BO, Difede J, Rizzo AA, Edwards-Stewart A, Skopp NA, Mishkind M, Reger MA, Gahm GA. Randomized controlled trial of prolonged exposure using imaginal exposure vs. virtual reality exposure in active duty soldiers with deployment-related posttraumatic stress disorder (PTSD). J Consult Clin Psychol. 2016 Nov;84(11):946-959. doi: 10.1037/ccp0000134. Epub 2016 Sep 8. PMID: 27606699.

81. Anderson PL, Price M, Edwards SM, Obasaju MA, Schmertz SK, Zimand E, Calamaras MR. Virtual reality exposure therapy for social anxiety disorder: a randomized controlled trial. J Consult Clin Psychol. 2013 Oct;81(5):751-60. doi: 10.1037/a0033559. Epub 2013 Jun 24. PMID: 23796315.
82. Tortella-Feliu M, Botella C, Llabrés J, Bretón-López JM, del Amo AR, Baños RM, Gelabert JM. Virtual reality versus computeraided exposure treatments for fear of flying. Behav Modif. 2011 Jan;35(1):3-30. doi: 10.1177/0145445510390801. PMID: 21177516.

83. Wallach HS, Safir MP, Bar-Zvi M. Virtual reality cognitive behavior therapy for public speaking anxiety: a randomized clinical trial. Behav Modif. 2009 May;33(3):314-38. doi: 10.1177/0145445509331926. Epub 2009 Mar 25. PMID: 19321811.

84. Botella C, García-Palacios A, Villa H, Baños RM, Quero S, Alcañiz M, Riva G. Virtual reality exposure in the treatment of panic disorder and agoraphobia: A controlled study. Clin Psychol Psychother. 2007 May;14(3):164-75. doi:10.1002/cpp.524

85. Chirită V, Ilinca M, Chiriţă R, Bîşcă M, Chele G, et al. Virtual therapy in patients with depression. Preliminary observation. Annu Rev CyberTherapy Telemed. 2006;9(6):664-5.

86. Huang MP, Himle J, Alessi NE. Vivid visualization in the experience of phobia in virtual environments: Preliminary results. CyberPsychology \& Behavior. 2000;3(3). doi:10.1089/10949310050078742.

87. Rus-Calafell M, Gutiérrez-Maldonado J, Botella C, Baños RM. Virtual reality exposure and imaginal exposure in the treatment of fear of flying: a pilot study. Behav Modif. 2013 Jul;37(4):568-90. doi: 10.1177/0145445513482969. Epub $2013 \mathrm{Apr}$ 12. PMID: 23585557.

88. McLay RN, Baird A, Webb-Murphy J, Deal W, Tran L, Anson H, Klam W, Johnston S. A Randomized, Head-to-Head Study of Virtual Reality Exposure Therapy for Posttraumatic Stress Disorder. Cyberpsychol Behav Soc Netw. 2017 Apr;20(4):218-224. doi: 10.1089/cyber.2016.0554. Epub 2017 Feb 27. PMID: 28394217.

89. Pelissolo A, Zaoui M, Aguayo G, Yao SN, Roche S, Ecochard R, Gueyffier F, Pull C, Berthoz A, Jouvent R, Cottraux J. Virtual reality exposure therapy versus cognitive behavior therapy for panic disorder with agoraphobia: a randomized comparison study. J CyberTherapy Rehabil. 2012 Mar 1;5(1):35-43.

90. Robillard G, Bouchard S, Dumoulin S, Guitard T, Klinger E. Using virtual humans to alleviate social anxiety: preliminary report from a comparative outcome study. Stud Health Technol Inform. 2010;154:57-60. doi:10.3233/978-1-60750-561-7-57. PMID: 20543270.

91. Roy MJ, Francis J, Friedlander J, Banks-Williams L, Lande RG, Taylor P, Blair J, McLellan J, Law W, Tarpley V, Patt I. Improvement in cerebral function with treatment of posttraumatic stress disordera. NYASA. 2010 Oct;1208(1):142-9. doi:10.1111/j.17496632.2010.05689.x

92. de Quervain DJ, Bentz D, Michael T, Bolt OC, Wiederhold BK, Margraf J, Wilhelm FH. Glucocorticoids enhance extinctionbased psychotherapy. Proc Natl Acad Sci U S A. 2011 Apr 19;108(16):6621-5. doi: 10.1073/pnas.1018214108. Epub 2011 Mar 28. PMID: 21444799; PMCID: PMC3081033.

93. Difede J, Cukor J, Wyka K, Olden M, Hoffman H, Lee FS, Altemus M. D-cycloserine augmentation of exposure therapy for posttraumatic stress disorder: a pilot randomized clinical trial. Neuropsychopharmacology. 2014 Apr;39(5):1052-8. doi: 10.1038/ npp.2013.317. Epub 2013 Nov 12. PMID: 24217129; PMCID: PMC3957110.

94. Mühlberger A, Wiedemann G, Pauli P. Efficacy of a one-session virtual reality exposure treatment for fear of flying. Psychother Res. 2003 Jan 1;13(3):323-36. doi: 10.1093/ptr/kpg030. PMID: 21827246.

95. Pallavicini F, Algeri D, Repetto C, Gorini A, Riva G. Biofeedback, virtual reality and mobile phones in the treatment of Generalized 
Anxiety Disorder (GAD): A phase-2 controlled clinical trial. J Cyber Ther Rehabil. 2009 Dec 1;2(4):315-27.

96. Perpiñá C, Botella C, Baños R, Marco H, Alcañiz M, Quero S. Body image and virtual reality in eating disorders: is exposure to virtual reality more effective than the classical body image treatment? Cyberpsychol Behav. 1999;2(2):149-55. doi: 10.1089/ cpb.1999.2.149. PMID: 19178251.

97. Ressler KJ, Rothbaum BO, Tannenbaum L, Anderson P, Graap $K$, Zimand $E$, Hodges L, Davis M. Cognitive enhancers as adjuncts to psychotherapy: use of D-cycloserine in phobic individuals to facilitate extinction of fear. Arch Gen Psychiatry. 2004 Nov;61(11):1136-44. doi: 10.1001/archpsyc.61.11.1136. PMID: 15520361.

98. Rothbaum BO, Price M, Jovanovic T, Norrholm SD, Gerardi M, Dunlop B, Davis M, Bradley B, Duncan EJ, Rizzo A, Ressler KJ. A randomized, double-blind evaluation of D-cycloserine or alprazolam combined with virtual reality exposure therapy for posttraumatic stress disorder in Iraq and Afghanistan War veterans. Am J Psychiatry. 2014 Jun;171(6):640-8. doi: 10.1176/ appi.ajp.2014.13121625. PMID: 24743802; PMCID: PMC4115813.

99. Shiban Y, Pauli P, Mühlberger A. Effect of multiple context exposure on renewal in spider phobia. Behav Res Ther. 2013 Feb;51(2):68-74. doi: 10.1016/j.brat.2012.10.007. Epub 2012 Nov 11. PMID: 23261707.

100. Shiban Y, Schelhorn I, Pauli P, Mühlberger A. Effect of combined multiple contexts and multiple stimuli exposure in spider phobia: A randomized clinical trial in virtual reality. Behav Res Ther. 2015 Aug;71:45-53. doi: 10.1016/j.brat.2015.05.014. Epub 2015 May 28. PMID: 26072451.

101. Shiban Y, Peperkorn H, Alpers GW, Pauli P, Mühlberger A. Influence of perceptual cues and conceptual information on the activation and reduction of claustrophobic fear. J Behav Ther Exp Psychiatry. 2016 Jun;51:19-26. doi: 10.1016/j.jbtep.2015.11.002. Epub 2015 Nov 26. PMID: 26687921.

102. Shiban Y, Diemer J, Müller J, Brütting-Schick J, Pauli P, Mühlberger A. Diaphragmatic breathing during virtual reality exposure therapy for aviophobia: functional coping strategy or avoidance behavior? a pilot study. BMC Psychiatry. $2017 \mathrm{Jan}$ 18;17(1):29. doi: 10.1186/s12888-016-1181-2. PMID: 28100203; PMCID: PMC5242013.

103. Freeman D, Bradley J, Antley A, Bourke E, DeWeever N, Evans N, Černis E, Sheaves B, Waite F, Dunn G, Slater M, Clark DM. Virtual reality in the treatment of persecutory delusions: randomised controlled experimental study testing how to reduce delusional conviction. Br J Psychiatry. 2016 Jul;209(1):62-7. doi: 10.1192/ bjp.bp.115.176438. Epub 2016 May 5. PMID: 27151071; PMCID: PMC4929408.

104. Tart CD, Handelsman PR, Deboer LB, Rosenfield D, Pollack MH, Hofmann SG, Powers MB, Otto MW, Smits JA. Augmentation of exposure therapy with post-session administration of D-cycloserine. J Psychiatr Res. 2013 Feb;47(2):168-74. doi: 10.1016/j.jpsychires.2012.09.024. Epub 2012 Oct 23. PMID: 23098672; PMCID: PMC3732105.

105. Gorini A, Pallavicini F, Algeri D, Repetto C, Gaggioli A, Riva G. Virtual reality in the treatment of generalized anxiety disorders. Stud Health Technol Inform. 2010;154:39-43. doi:10.3233/978-160750-561-7-39. PMID: 20543266.

106. Herrmann MJ, Katzorke A, Busch Y, Gromer D, Polak T, Pauli P, Deckert J. Medial prefrontal cortex stimulation accelerates therapy response of exposure therapy in acrophobia. Brain Stimul. 2017 Mar-Apr;10(2):291-297. doi: 10.1016/j.brs.2016.11.007. Epub 2016 Nov 14 PMID: 27931887.

107. Hoffman HG, Garcia-Palacios A, Carlin A, Furness lii TA, BotellaArbona C. Interfaces that heal: coupling real and virtual objects to treat spider phobia. Int J Hum Comput Interact. 2003 Oct 1;16(2):283-300. doi:10.1207/S15327590IJHC1602_08.

108. Kleim B, Wilhelm FH, Temp L, Margraf J, Wiederhold BK, Rasch B. Sleep enhances exposure therapy. Psychol Med. 2014 May;44(7):1511-9. doi: 10.1017/S0033291713001748. Epub 2013 Jul 10. PMID: 23842278.

109. Krijn M, Emmelkamp PM, Olafsson RP, Schuemie MJ, van der Mast $C A$. Do self-statements enhance the effectiveness of virtual reality exposure therapy? A comparative evaluation in acrophobia. Cyberpsychol Behav. 2007 Jun;10(3):362-70. doi: 10.1089/ cpb.2006.9943. PMID: 17594260.

110. Malbos E, Rapee RM, Kavakli M. Isolating the effect of Virtual Reality Based Exposure Therapy for agoraphobia: a comparative trial. Stud Health Technol Inform. 2011;167:45-50. PMID: 21685640.21.

111. Maples-Keller JL, Price M, Jovanovic T, Norrholm SD, Odenat L, Post L, Zwiebach L, Breazeale K, Gross R, Kim SJ, Rothbaum BO. Targeting memory reconsolidation to prevent the return of fear in patients with fear of flying. Depress Anxiety. 2017 Jul;34(7):610-620. doi: 10.1002/ da.22626. Epub 2017 Apr 5. PMID: 28380277.

112. Botella Arbona C, Bretón-López J, Serrano Zárate B, García-Palacios A, Quero S, Baños Rivera RM. Treatment of flying phobia using virtual reality exposure with or without cognitive restructuring: Participants' preferences. Rev Psicopatol y Psicol Clin. 2014 Dec 1;19(3):157-69. doi:10.5944/rppc.vol.19.num.3.2014.13898.

113. Quero S, Pérez-Ara MÁ, Bretón-López J, García-Palacios A, Baños RM, Botella C. Acceptability of virtual reality interoceptive exposure for the treatment of panic disorder with agoraphobia. British Journal of Guidance \& Counselling. 2014 Mar 15;42(2):123-37. doi: 10.1080/03069885.2013.852159

114. Emmelkamp PM, Krijn M, Hulsbosch AM, de Vries S, Schuemie $\mathrm{MJ}$, van der Mast CA. Virtual reality treatment versus exposure in vivo: a comparative evaluation in acrophobia. Behav Res Ther. 2002 May;40(5):509-16. doi: 10.1016/s0005-7967(01)00023-7. PMID: 12038644.

115. Levy F, Leboucher P, Rautureau G, Jouvent R. E-virtual reality exposure therapy in acrophobia: A pilot study. J Telemed Telecare. 2016 Jun;22(4):215-20. doi: 10.1177/1357633X15598243. Epub 2015 Aug 6. PMID: 26253746.

116. Lindner $P$, Miloff A, Fagernäs $S$, Andersen J, Sigeman $M$, Andersson $G$, Furmark T, Carlbring P. Therapist-led and self-led one-session virtual reality exposure therapy for public speaking anxiety with consumer hardware and software: A randomized controlled trial. J Anxiety Disord. 2019 Jan;61:45-54. doi: 10.1016/j.janxdis.2018.07.003. Epub 2018 Jul 24. Erratum in: J Anxiety Disord. 2019 May;64:90. PMID: 30054173.

117. Stupar-Rutenfrans S, Ketelaars LEH, van Gisbergen MS. Beat the Fear of Public Speaking: Mobile $360^{\circ}$ Video Virtual Reality Exposure Training in Home Environment Reduces Public Speaking Anxiety. Cyberpsychol Behav Soc Netw. 2017 Oct;20(10):624-633. doi: 10.1089/ cyber.2017.0174. PMID: 29039704.

118. Baños RM, Botella C, Perpiñá C, Alcañiz M, Lozano JA, Osma J, Gallardo M. Virtual reality treatment of flying phobia. IEEE Trans Inf Technol Biomed. 2002 Sep;6(3):206-12. doi: 10.1109/titb.2002.802380. PMID: 12381036.

119. Coelho CM, Santos JA, Silvério J, Silva CF. Virtual reality and acrophobia: one-year follow-up and case study. Cyberpsychol Behav. 2006 Jun;9(3):336-41. doi: 10.1089/cpb.2006.9.336. PMID: 16780401. 
120. Côté S, Bouchard S. Documenting the efficacy of virtual reality exposure with psychophysiological and information processing measures. Appl Psychophysiol Biofeedback. 2005 Sep;30(3):217-32. doi: 10.1007/s10484-005-6379-x. PMID: 16167187.

121. Riva G, Bacchetta M, Baruffi M, Cirillo G, Molinari E. Virtual reality environment for body image modification: A multidimensional therapy for the treatment of body image in obesity and related pathologies. CyberPsychology Behav. 2000 Jun;1;3(3):421-31. doi: 10.1089/10949310050078887.

122. Botella C, Villa H, García Palacios A, Quero S, Baños RM, Alcaniz M. The use of VR in the treatment of panic disorders and agoraphobia. Stud Health Technol Inform. 2004;99:73-90. doi: 10.3233/978-1-60750-9431-73. PMID: 15295147.

123. Pelissolo A, Zaoui M, Aguayo G, Yao SN, Roche S, Ecochard R, Gueyffier F, Pull C, Berthoz A, Jouvent R, Cottraux J. Virtual reality exposure therapy versus cognitive behavior therapy for panic disorder with agoraphobia: a randomized comparison study. J Cybertherapy Rehabil. 2012 Mar;1;5(1):35-43.

124. Marco JH, Perpiñá C, Botella C. Effectiveness of cognitive behavioral therapy supported by virtual reality in the treatment of body image in eating disorders: one year follow-up. Psychiatry Res. 2013 Oct 30;209(3):619-25. doi: 10.1016/j.psychres.2013.02.023. Epub 2013 Mar 15. PMID: 23499231.

125. Rus-Calafell M, Gutiérrez-Maldonado J, Botella C, Baños RM. Virtual reality exposure and imaginal exposure in the treatment of fear of flying: a pilot study. Behav Modif. 2013 Jul;37(4):568-90. doi: 10.1177/0145445513482969. Epub 2013 Apr 12. PMID: 23585557.

126. Roy MJ, Francis J, Friedlander J, Banks-Williams L, Lande RG, Taylor P, Blair J, McLellan J, Law W, Tarpley V, Patt I, Yu H, Mallinger A, Difede J, Rizzo A, Rothbaum B. Improvement in cerebral function with treatment of posttraumatic stress disorder. Ann N Y Acad Sci. 2010 Oct;1208:142-
9. doi: 10.1111/j.1749-6632.2010.05689.x. PMID: 20955336.

127. Beidel DC, Frueh BC, Neer SM, Bowers CA, Trachik B, Uhde TW, Grubaugh A. Trauma management therapy with virtual-reality augmented exposure therapy for combat-related PTSD: A randomized controlled trial. J Anxiety Disord. 2019 Jan;61:64-74. doi: 10.1016/j. janxdis.2017.08.005. Epub 2017 Aug 23. PMID: 28865911.

128. Lima J, McCabe-Bennett $\mathrm{H}$, Antony MM. Treatment of Storm Fears Using Virtual Reality and Progressive Muscle Relaxation. Behav Cogn Psychother. 2018 Mar;46(2):251-256. doi: 10.1017/ S1352465817000674. Epub 2017 Oct 30. PMID: 29081326.

129. Maltby N, Kirsch I, Mayers M, Allen GJ. Virtual reality exposure therapy for the treatment of fear of flying: a controlled investigation. J Consult Clin Psychol. 2002 Oct;70(5):1112-8. doi: 10.1037//0022006x.70.5.1112. PMID: 12362961.

130. Tortella-Feliu M, Botella C, Llabrés J, Bretón-López JM, del Amo AR, Baños RM, Gelabert JM. Virtual reality versus computer-aided exposure treatments for fear of flying. Behav Modif. 2011 Jan;35(1):330. doi: 10.1177/0145445510390801. PMID: 21177516.

131. Glantz K, Durlach NI, Barnett RC, Aviles WA. Virtual reality (VR) and psychotherapy: opportunities and challenges. Presence (Camb). 1997 Feb;6(1):87-105. doi: 10.1162/pres.1997.6.1.87. PMID: 11540645.

132. Fodor LA, Coteț CD, Cuijpers P, Szamoskozi Ș, David D, Cristea IA. The effectiveness of virtual reality based interventions for symptoms of anxiety and depression: A meta-analysis. Sci Rep. 2018 Jul 9;8(1):10323. doi: 10.1038/s41598-018-28113-6. PMID: 29985400; PMCID: PMC6037699.

133. Shah LB, Torres $S$, Kannusamy $P$, Chng CM, He HG, Klainin-Yobas $P$. Efficacy of the virtual reality-based stress management program on stress-related variables in people with mood disorders: the feasibility study. Arch Psychiatr Nurs. 2015 Feb;29(1):6-13. doi: 10.1016/j. apnu.2014.09.003. Epub 2014 Sep 10. PMID: 25634868. 